\title{
KEGIATAN BAKTI SOSIAL DONOR DARAH DI STKIP PGRI METRO "BERBAGI INDAH MEMBAWA BERKAH"
}

\author{
Eka Fitri Hastuti ${ }^{1}$, Arum Sulastri ${ }^{2}$, Joko Santoso ${ }^{3}$ \\ STKIP PGRI Metro \\ Jl. Ki Hajar Dewantara No.38B, Banjar Rejo, Batanghari, \\ Kabupaten Lampung Timur, Lampung \\ Fitrihastuti2507@gmail.com¹, arumsulas3@gmail.com², joko.spbsi@gmail.com ${ }^{3}$
}

\begin{abstract}
The purpose of the blood donation social service with the theme of sharing is beautiful and brings blessing is to provide UTD-PMI Metro City help in increasing blood reserves so that it can meet blood needs in Metro City as well as socializing blood donation activities on the STKIP PGRI Metro campus for the communitycampus and around campus. This activity was held on July 8, 2020 at the STKIP PGRI Metro campus. This blood donation social service activity was attended by 70 participants who came from students, lecturers, BEM, education personnel and the general public. Based on gender, the participants in this activity were dominated by women (38 people) and the rest were men (32 people). The number of blood bags that can be collected during this activity is 70 blood bags. Blood donation activities that are attractively packaged, published and involve organizations / institutions can increase the level of community participation.
\end{abstract}

Keywords:Blood donation, Social Service, STKIP PGRI Metro, UTD-PMI Metro City

\begin{abstract}
Abstrak: Tujuan dari kegiatan bakti sosial donor darah yang bertemakan berbagi itu indah dan membawa keberkahan ini adalah untuk memberikan pertolongan UTD-PMI Kota Metro dalam menambah cadangan darah sehingga dapat mencukupi keperluan darah di Kota Metro serta melakukan sosialisasi kegiatan donor darah di kampus STKIP PGRI Metro bagi masyarakat kampusdan disekitar kampus. Kegiatan ini dilaksanakan pada tanggal 8 Juli 2020 di kampus STKIP PGRI Metro. Kegiatan bakti sosial donor darah ini diikuti oleh 70 partisipan yang berasal dari mahasiswa, dosen, BEM, Tenaga Kependidikan serta masyarakat umum. Berdasarkan jenis kelamin, peserta kegiatan ini didominasi oleh perempuan (38 Orang) dan sisanya laki-laki (32 Orang). Jumlah kantong darah yang dapat dikumpulkan selama kegiatan ini adalah 70 kantong darah. Kegiatan donor darah yang dikemas secara menarik, publikasi dan melibatkan organisasi/ lembaga dapat meningkatkan tingkat partisipasi masyarakat.
\end{abstract}

Kata Kunci: Donor darah, Bakti Sosial, STKIP PGRI Metro, UTD-PMI Kota Metro.

$\mathrm{D}$ arah manusia adalah cairan jaringan tubuh yang dapat menjadi gambaran untuk keadaan tubuh kita. Darah merupakan cairan yang sangat penting bagi setiap manusia, hal ini dikarenakan salah satu fungsi darah sebagai alat transportasi serta mempunyai fungsi lainnya sebagai penunjang kehidupan. Seseorang yang tidak cukup darah dapat mengalami gangguan kesehatan dan bahkan dapat mengakibatkan kematian.Darah yang beredar dalam tubuh dapat menghangatkan, mendinginkan dan melindungi tubuh dari zat beracun, selain itu darah mampu memperbaiki kerusakan apapun pada dinding pembuluh darah dan dapat 
diremajakan kembali. Darah dalam tubuh manusia terdiri dari 55\% plasma darah (cairan darah) dan 45\% sel-sel darah sedangkan jumlah darah yang berada pada tubuh kita sekitar sepertiga belas berat badan orang dewasa atau sekitar 4-5 liter, komponen darah yang ada pada manusia terdiri dari sel darah merah, sel darah putih dan trombosit. Menurut Devie Rosa Anamisa (2015: 1) mengungkapkan bahwa fungsi utama dari darah khususnya sel darah merah yang dikenal dengan eritrosit yaitu mengangkut hemoglobin, dan seterusnya mengangkut oksigen dari paru-paru ke jaringan.

Menurut Khairil Fitryadi, Sutikno (2016: 1) Darah terdiri dari cairan kompleks plasma tempat elemen selular diantaranya eritrosit, leukosit, dan trombosit. Eritrosit (sel darah merah) pada hakikatnya adalah kantung hemogoblin terbungkus membran plasma yang mengangkut O2 dalam darah. Leukosit (sel darah putih) satuan pertahanan sistem imun, diangkut dalam darah tempat cedera atau tempat invasi mikro organisme penyebab penyakit. Trombosit penting dalam homeostasis, penghentian pendarahan dari pembuluh yang cedera. Adapun menurut Anis Nur Khasanah \& Suyadi (2014: 7) menjelaskan bahwa fungsi utama darah adalah sebagai media atau sarana transportasi, memelihara suhu dan memelihara asam dan basa cairan tubuh. Trombosit (platelet) merupakan salah satu komponen darah yang berupa fragmen sitoplasma megakariosit yang tidak berinti, mempunyai ukuran yang lebih kecil dari sel darah merah atau sel darah putih. Trombosit berfungsi sebagai bagian dari mekanisme perlindungan darah untuk menghentikan perdarahan. Dapat dikatakan bahwa trombosit memiliki tugas untuk mengumpulkan darah, hal tersebut dilakukan untuk mengurangi darah keluar pada saat luka. Jadi darah di dalam tubuh memiliki banyak sekali fungsi selain untuk menyalurkan gizi dan mineral yang diperlukan tubuh, darah berfungsi pengantar oksigen dari paru-paru dan mengangkat karbondioksida yang mengakibatkan kita dapat beraktivitas, mempunyai antibodi/sistem imun yang tidak mudah terserang penyakit, menjaga kadar asambasa cairan tubuh dan pengontrol suhu badan.

Pemasukan darah atau disebut juga transfusi darah merupakan suatu aktivitas medis yang mempunyai tujuan mengubah komponen darah yang berkurang. Transfusi darah menjadi salah satu upaya kesehatan sebagai proses penyaluran darah baik berupa darah lengkap atau komponen darah orang ke sistem peredaran darah ke orang lain untuk pemulihan kesehatannya (Departemen Kesehatan RI, 2001). Transfusi darah merupakancara pemindahan darah dari seseorang yang sehat (donor) ke orang tidak sehat (resipien). Darah yang dipindahkan dapat berupa darah lengkap dan komponen darah(https://rsudza.acehprov.go.id/).

Unit Transfusi Darah (UTD) merupakan pelayanan kesehatan yang memanfaatkan darah manusia sebagai fokus utama dengan tujuan pemenuhan darah bagi sesorang yang 
memerlukan darah untuk menolong jiwanya. Darah tidak dijual dengan alasan apapun. Unit Transfusi darah (UTD) sebagai salah satu usaha kesehatan untuk dapat sembuh dari penyakit dan pemulihan kesehatan yang menyediakan komponen darah yang cukup, aman, bermanfaat, mudah diakses dan terjangkau sesuai kebutuhan masyarakat. Menurut Anis Nur Khasanah \& Suyadi (2014: 17) menjelaskan bahwa upaya kesehatan transfusi darah merupakan tindakan yang dilakukan dengan tujuan untuk memungkinkan penggunaan darah bagi keperluan pengobatan dan pemulihan kesehatan. Sedangkan pendonor darah yaitu proses pengambilan darah dari seseorang secara sukarela untuk disimpan di bank darah sebagai stok darah untuk kemudian digunakan untuk transfusi darah. Terdapat dua jenis donor darah, yaitu donor darah pengganti dan donor darah langsung.

Donor darah diatur dalam Peraturan Pemerintah (PP) no 7/ 2011 tentang pelayanan darah. PP tersebut menjelaskan penyelenggaran donor darah dan pengolahan darah yang dilakukan oleh Unit Donor Darah (UDD) yang diselenggarakan Palang Merah Indonesia (PMI). Pendonor darah dapat melakukan donor darah di unit donor darah (UDD) PMI Pusat maupun daerah setempat. Kegiatan promosi darah atau penyelenggaran sumbangan darah dapat dilakukan melalui media televisi, media massa dan cetak, menempatkan mobimobil unit ditempat strategis, sosial media dan website serta tempat keramaian (pasar, sekolah, perguruan tinggi). Pemenuhan kebutuhan darah di bank darah sangatlah penting bagi seseorang yang mengalami sakit, setetes darah dapat menyelamatkan nyawa seseorang sehingga dapat dikatakan bahwa transfusi darah dibutuhkan oleh mereka yang sedang mengalami kebutuhan darah akibat kecelakaan dengan kondisi darurat, pasien operasi besar, seperti operasi jantung, bedah perut, seksio, sesarea, leukimia, hemofilia dan thalassemia (Teguh Pribadi 2017: 50)

Seiring dengan banyaknya keperluan darah yang terus meningkat sehingga mengakibatkan kesenjangan antara jumlah persediaan dengan kebutuhan darah di beberapa UTD sehingga memicu terjadi ketidak cukupan darah di UTD PMI khususnya propinsi Lampung.Kepala UTD PMI Lampung dr. Aditya M. Biomed membenarkan pandemi covid 19 mengakibatkan terjadinya kelangkaan pasokan darah di provinsi Lampung.(http://haluanlampung.com/).PMI mengalami kekurangan stok darah selama adanya Covid19 ini, ketidak cukupan darah di UTD dapat disebabkan oleh sedikitnya jumlah dari donor darah sukarela yang biasanya rutin dan aktif melaksanakan donor darah dikarenakan selama terjadi Pandemi Covid-19, pendonor darah tidak melakukan kegiatan donor darah sehingga pasokan darah ke PMI Kota Metro menurun drastis (http://harianmomentum.com/). Berdasarkan hal tersebut kami melaksanakan kegiatan 
bakti sosial donor darah dalam rangka meningkatkan keikutsertaan masyarakat untuk melaksanakan kegiatan donor darah dengan mengikutsertakan UTD-PMI Metro dan BEM STKIP PGRI Metro sekaligus menambah pasokan darah agar dapat tercukupi.

\section{Tujuan}

Tujuan dari adanya kegiatan bakti sosial ini adalah:

a. Menolong UTD-PMI Kota Metro untuk menambah pasokan cadangan darah sehingga dapat mencukupi kebutuhan darah di Kota Metro.

b. Melaksanakan sosialisasi adanya kegiatan donor darah bagi masyarakat sekitar kampus.

\section{Sasaran}

a. Masyarakat kampusyang terdiri dari tenaga pengajar, tenaga kependidikan dan mahasiswa

b. Masyarakat umum yaitu TNI/Polri, lembaga pemerintah dan swasta

\section{Luaran danManfaat}

Kegiatan ini diharapkan menghasilkan banyak kantung darah dari para pendonor sekaligus pendonor darah dapat bertambah. Sedangkan manfaatnya, kegiatan ini dapat membantu UTD-PMI Kota Metro untuk melakukan sosialisasi kegiatan donor darah kepada masyarakat.

\section{METODE}

\section{Waktu dan Tempat kegiatan}

Pelaksanaan Kegiatan pada hari Rabu, 8 Juli 2020. Tempat kegiatan bakti sosial ini dilaksanakan di STKIP PGRI Metro, Jalan Ki Hajar Dewantara No.38B, Banjar Rejo, Batanghari, Kabupaten Lampung Timur, Lampung 34381

\section{PelaksanaanKegiatan.}

Pelaksanaan kegiatan meliputi kegiatan sebagai berikut:

a. Persiapan kegiatan dilakukan dengan melakukan koordinasi dengan UTD- PMI Kota Metro dan anggota BEM STKIP PGRI Metro. Persiapan ini dilakukan untuk menyiapkan sarana prasarana dan kelengkapan untuk kegiatan bakti sosial donor darah, serta penetapan pelaksanaan kegiatantersebut.

b. Kegiatan bakti sosial dilaksanakan sejak pukul 09.30-selesai di kampus STKIP PGRI Metro. Kegiatan dimulai dengan sambutan dari Ketua STKIP PGRI Metro. Para 
masyarakat yang akan mendonorkan darahnya terlebih dahulu didaftar oleh panitia dari BEM STKIP PGRI Metro, kemudian mereka diperiksa kesehatanya oleh petugas UTD-PMI Kota Metro. Pendonor darah yang dinyatakan sehat dapat memasuki ruangan pengambilan darah. Peserta kegiatan donor darah disuguhi hiburan sambil menunggu giliran untuk melakukan donordarah.

c. Di akhir kegiatan, dilakukan pembagian door prize donatur kegiatan bakti sosial.

\section{HASIL DAN PEMBAHASAN}

\section{Hasil}

Dalam kegiatan yang bertema berbagi indah membawa berkah ini menyertakan tenaga pendidik dan peserta didik, UTD-PMI Kota Metro dan relasi dalam pendanaan dan penerbitan.Perwakilan dari pendonor darah antara lainDosen dan Tenaga kependidikan, Anggota BEM STKIP PGRI Metro, anggota Menwa STKIP PGRI Metro, mahasiswamahasiswa STKIP PGRI Metro dari Prodi PGSD, PBA, PBI PAUD, dan masyarakat.

Jumlah pendonor darah sebanyak70orang pendonor. Penyumbang terbanyak darimahasiswa sebanyak 50pendonor. Urutan keduapeserta donor darah adalah masyarakat sebanyak 10 pendonor, posisi ketiga dosen dan tenaga kependidikan sebanyak10 orang. Pendonorperempuan mendominasi jumlah peserta donor darah dalam kegiatan ini,ada 38perempuan yang menjadi peserta donor darah dan sisanya adalah laki-laki sebanyak 32 orang (Tabel1).Jumlah kantung darah yang terkumpul dari kegiatan ini sebanyak 70 kantung darah. Kantung darah sebanyak 70 berasal dari 70pendonor yang dinyatakan sehat dan diperbolehkan melakukan donor darah.

Tabel 1. Jumlah pendonor darah berdasarkan asal, jenis kelamin, dan tindakan donordarah.

\begin{tabular}{lcccccc}
\hline \multirow{2}{*}{ Asal peserta } & \multicolumn{2}{c}{ Jenis Kelamin } & \multirow{2}{*}{ Jumlah } & \multicolumn{2}{c}{ Donor darah } \\
\cline { 2 - 3 } \cline { 5 - 6 } & Laki-laki & Perempuan & & Ya & Tidak \\
\hline Dosen & 3 & 3 & 6 & & $\sqrt{ }$ & - \\
Mahasiswa & 11 & 15 & 26 & & $\sqrt{ }$ & - \\
Menwa & 6 & 8 & 14 & & $\sqrt{ }$ & - \\
BEM & 7 & 3 & 10 & & $\sqrt{ }$ & - \\
Tenaga kependidikan & 1 & 3 & 4 & & $\sqrt{ }$ & - \\
Masyarakat & 4 & 6 & 10 & & $\sqrt{ }$ & - \\
Jumlah & 32 & 38 & 70 & & - \\
\hline
\end{tabular}



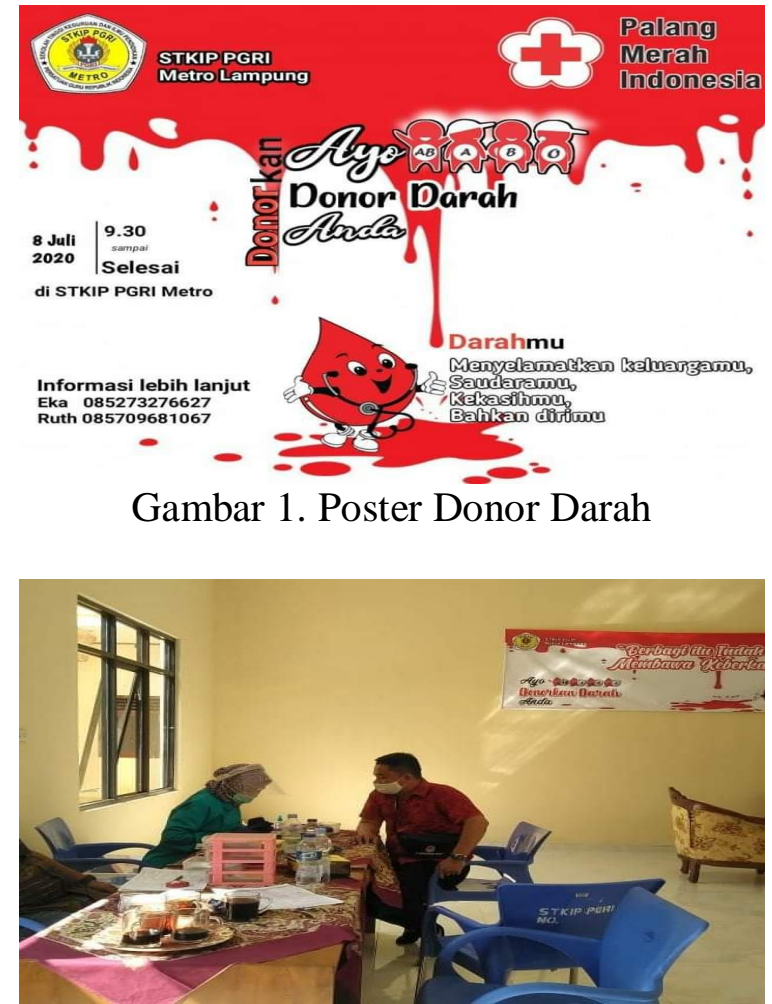

Gambar 3.Pendaftaran peserta kegiatan bakti sosial donor darah

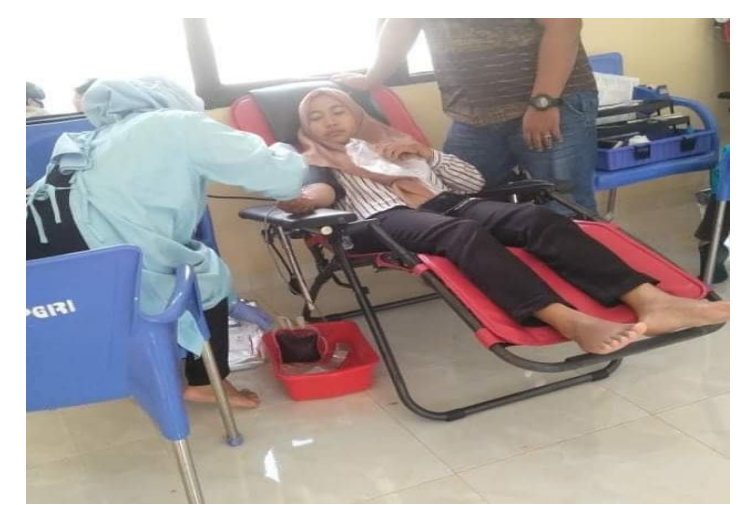

Gambar 5.Pelaksanaan Donor darah

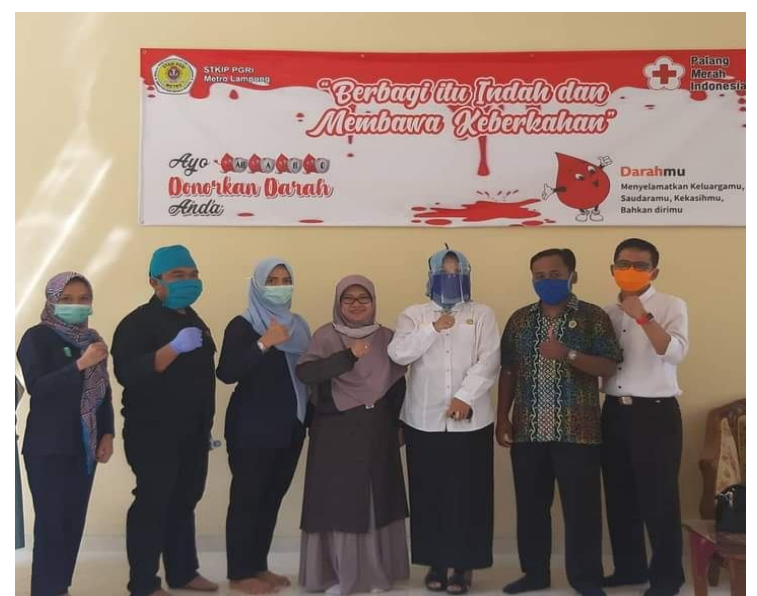

Gambar 7. Foto bersama antara panitia dan petugas UTD-PMI Kota Metro

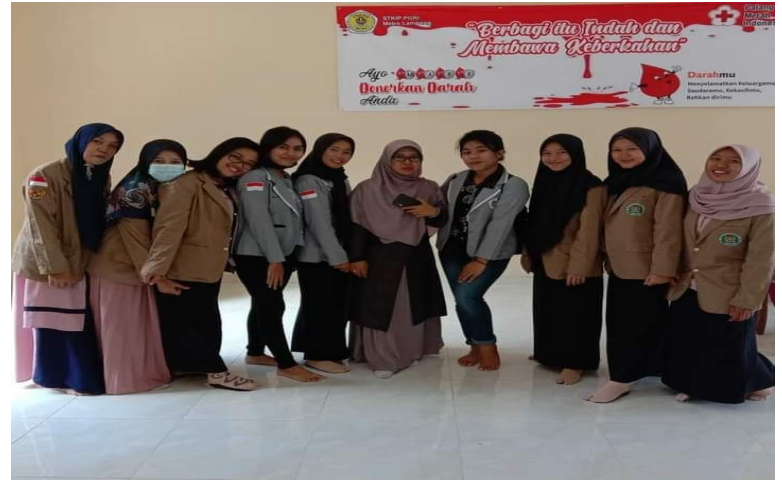

Gambar 2.Para Perwakilan kegiatan bakti sosial donor darah

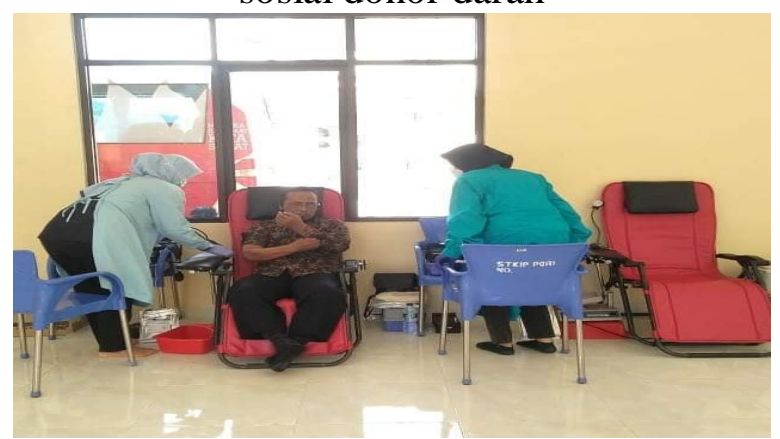

Gambar 4.Pemeriksaan Kesehatan

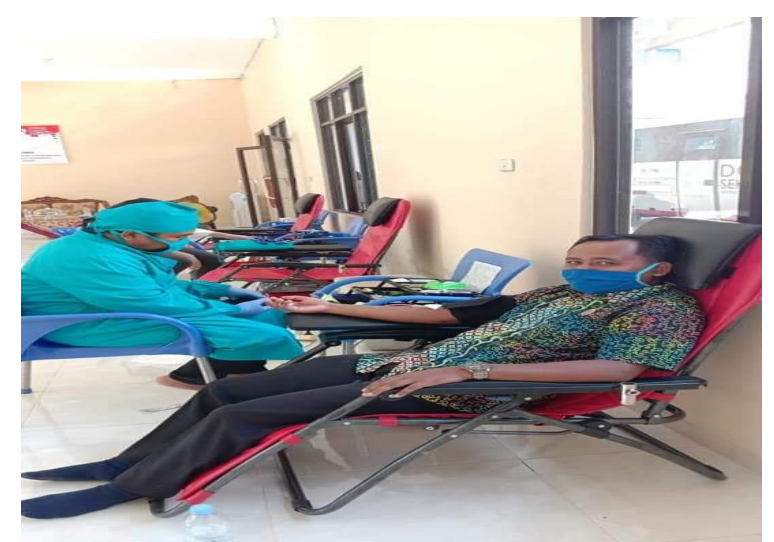

Gambar 6. Pelaksanaan Donor darah

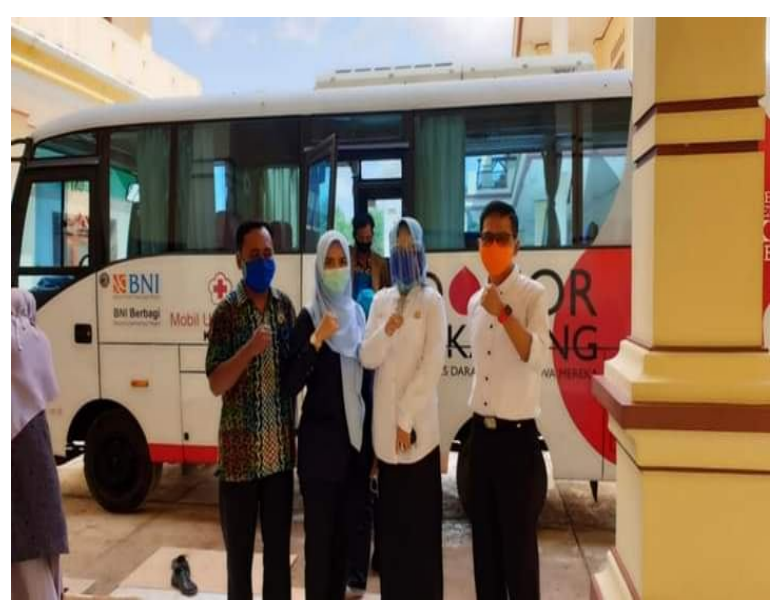

Gambar 8. Foto bersama antara panitia dan petugas UTD-PMI Kota Metro 


\section{Pembahasan}

Seluruh kegiatan bakti sosial donor darah yang diadakan di lingkungan STKIP PGRI Metro ini dapat dikatakan terlaksana dengan sukses dan lancar, di mana ukuran dari suksesnya kegiatan ini adalah para peserta bakti sosial mencapai 70 pendonor darah dan jumlah kantong darah mencapai 70 kantong darah atau kantong darah sama dengan jumlah peserta donor darahyang dapat dikatakan relatif cukup besar untuk memperoleh kantong darah. Para peserta dimungkinkan hadir karena adanya berbagai hiburan dan hadiah dari para penyumbang untuk para peserta donor darah yang beruntung. Adanya pemberitahuan di media cetak ataupun elektronik, pamflet dan undangan serta organisasi yang bersedia menjadi perserta donor darah sukarela merupakan salah satu kelancaran kegiatan yang diadakan. Seperti yang diungkapkan oleh Teguh Pribadi (2017: 55) Pemanfaatan media baik secara langsung maupun tidak langsung untuk mengkomunikasikan kegiatan donor darah dapat meningkatkan pemahaman dan partisipasi masyarakat untuk melakukan kegiatan donor darah.

Adanya partisipasi mahasiswa dan masyarakat mengakibatkan terkumpulnya banyak kantong darah. Berbagai penjelasanpengetahuan dari kampus STKIP PGRI Metro memicu mereka melakukan donor darah. Menurut Aditya Nugraha (2019: 316) Faktor yang mempengaruhi motivasi seseorang dalam melakukan donor darah antara lain pengetahuan, lingkungan, altruisme, dan pengalaman. Altruisme adalah suatu tindakan memberikan perhatian terhadap kesejahteraan orang lain atau bisa dikatakan membantu sesama tidak menginginkan keuntungan, walaupun dirinya menderita atau menanggung rugi (Burhan dalam Aditya Nugraha 2019: 316). Pengetahuan adalah ranah kognitif yang penting dalam tindakan seseorang karena tindakan yang didasari oleh pengetahuan bisatahan lama dibanding tindakan tanpa didasari oleh pengetahuan. Oleh karena itu pendonor darah yang mempunyai pengetahuan yang baik dapat terus mendonorkan darahnya secara teratur setiap tahunnya(Azwar, dalam Aditya Nugraha 2019: 316). Lingkungan sosial adalah salah satu faktor pendorong kemauan dan ketidak kemauan dari lingkungan sekitar.Faktor lingkungan merupakan faktor yang penting karena lingkungan akan sangat berpengaruh dalam memotivasi kehidupan seseorang misalkan tempat tinggal, pergaulan bersama teman, dorongan dan dukungan dari orang sekitar untuk melakukan suatu hal (Grossman, Watkins, Fleming, \& DeBaun, dalam Aditya Nugraha 2019: 316). Pengalaman akan melakukan sesuatu hal bisa di rasakan secara berbeda-beda karena pengalaman bersifat subjektif, segala sesuatu yang berkaitan dengan indera disimpan dalam memori dan digunakan sebagai referensi untuk menanggapi hal yang baru. 
Pengalaman melakukan donor darah sebelumnya dapat mempengaruhi seseorang untuk kembali mendonorkan darahnya di masa yang akan datang(Dubey, Soner \& Chaurasia dalam Aditya Nugraha 2019: 316). Selain itu motivasi seseorang melakukan donor darah adalah menurunkan resiko penyakit kardiovaskuler yaitu penyakit yang berkaiatan dengan jantung dan pembuluh darah (Nur Elvira \& Danarsih 2016: 2)

Jumlah kantung darah yang terkumpul adalah 70 kantung darah. Jumlah perempuan lebih dominan, karena banyaknya mahasiswa di STKIP PGRI Metro yang dominan perempuan. Walaupun banyak yang menyatakan bahwa perempuan umumnya rentan akan berbagai keluhan dari takutnya jarum suntik sampai dengan anemia dan proporsi bentuk dan berat badan yang tidak memenuhi kesehatan, akan tetapi mahasiswa STKIP PGRI Metro mayoritas perempuan sudah melakukan pengecekan dinyatakan sehat dan mempunyai metabolisme yang baik.

Metabolisme merupakan suatu proses daur ulang energi yang ada didalam tubuh. Metabolisme ini dipengaruhi oleh usia, ukuran tubuh, jenis kelamin, suhu tubuh, asupan makanan, hormon dan aktivitas manusia. Bertambahnya usia seseorang dapat mempengaruhi aktivitas yang semakin menurun dan bertambahnya usia juga mempengaruhi hormon yang diproduksi jumlahnya yang semakin dikit. Jika terdapat gangguan pada produksi hormon tiroid di dalam tubuh, maka laju metabolisme juga mengalami kendala menjadi lebih cepat ataupun lambat dari yang seharusnya tergantung dari kadar hormon yang terdapat di tubuh. Proses metabolisme merupakan hal yang sangat penting untuk tubuh sehingga saat ada gangguan maka penyakit yang timbul dapat berdampak cukup parah sehingga menjaga terus kadar metabolisme tubuh dengan rutin konsumsi makanan sehat dan olah raga yang teratur yang dapat menstabilkan volume darah. Menurut Anis Nur Khasanah\&Suyadi (2014: 20) metabolisme berkaitan erat denga pembentukan dan penguraian zat dan kemampuan metabolisme yang sering dikaitkan dengan usia seseorang, semakin bertambahnya usia seseorang maka kemampuannya dalam pembentukan dan penguraian zat akan berkurang pula. Maka dari itu dapat dikatakan bahwa seorang pendonor darah harus mempunyai metabolisme yang bagus dan sehat baik dari pihak laki-laki maupun perempuan.

\section{SIMPULAN}

Berbagi Indah Membawa Berkah yang merupakan tema dari bakti sosial ini dilaksanakan Hari Rabu 8 Juli 2020dengan partisipasi sebanyak 70 orang yang terdiri dari mahasiswa (26 orang), Anggota BEM (10 orang), anggota menwa (14orang), masyarakat 
umum (10 orang), dosen (6 orang), dan tenaga pendidik (4 orang). Kegiatan donor darah berjalan secara sukses dan lancar dilihat dari kantong darah yang terkumpul sebanyak 70 kantong diperoleh dari 70 pendonor darah yang dinyatakan sehat untuk dilakukan donor darah. Keikutsertaan masyarakat umum maupun kampus dalam kegiatan donor darah sangat antusias, serta dukungan dari kampus STKIP PGRI Metro berupa hiburan dan hadiah menambah minat para peserta donor darah.

\section{Saran}

Berbagi Indah Membawa Berkah yang merupakan tema dari bakti sosial donor darahyang diadakan di kampus STKIP PGRI Metro yangsangat memberikan manfaat dan diharapkan dapat dilakukan secara berkesinambungan,diagendakan secara rutin serta lebih mendapat dukungan dan partisipasi dari berbagai pihak. Kegiatan bakti sosial diadakan secara menarik yang dikemas dalam hiburan dan hadiah dapat meningkatkan keinginan dan motivasi masyarakat untuk mengikuti kegiatan bakti sosial.

\section{UCAPAN TERIMA KASIH}

Di ucapkan terima kasih kepada Ketua RSUD A. Yani Kota Metro, UTD-PMI Kota Metro, Ketua STKIP PGRI Metro.

\section{DAFTAR PUSTAKA}

Aditya Nugraha, Gamya Tri Utami,\& Rismadefi Woferst (2019). Faktor-faktor yang Berhubungan dengan Motivasi Mahasiswa Fakultas Keperawatan Universitas Riau dalam Melakukan Donor Darah. JOM FKp. Vol. 6 No. 1 (Januari-Juni) 2019 / 315324

Anis Nur Khasanah\&Suyadi. (2014). Studi Jumlah Trombositantara Pendonorlaki-lakidan Perempuanpada Usiayangberbedadi Unit Transfudi Darah Cabang Kota Malang. Florea. Volume 1 No. 1, April 2014 (17-22)

Devie Rosa Anamisa (2015). Rancang Bangun Metode OTSU Untuk Deteksi Hemoglobin. Jurnal Ilmu Komputer dan Sains Terapan. Jurnal S@CIES Volume x, Nomor x, April 2015, hlm 106-110

Khairil Fitriadi \& Sutikno (2016). Pengenalan Jenis Golongan Darah Menggunakan Jaringan Syaraf Tiruan. Jurnal Masyarakat Informatika. Volume 7, Nomor 1, ISSN 2086 4930. Hlm 1-10.

Nur Alvira \& Dwi Eni danarsih (2016). Frekuensi Donor Darah dapat mengendalikan Flator Resiko Penyakit Kardiovaskuler di Unit Donor Darah PMI Kabupaten Bantul. Jurnal Formil (Forum Ilmiah) KesMas Respati. Volume 1, Nomor , April 2016. ISSN 25025570. Hlm 1-11

Siti Fatimah, Mukhammad Akmal Surur, Muhammad A'tourrohman, Afinatur Rohmah, \& Fuadela Khumaera (2019). KOAGULASI DAN KOMPOSISI DARAH. Praktikum Fisiologi Hewan.https://www.researchgate.net/publication/ 
Siti Wulandari, Bagoes Widjanarko \& kusyogo. Analisis Niat Donor Darah Sukarela (DSS) Untuk Konseling Menerima Hasil Test di Unit Donor Darah (UDD) PMI Kabupaten Semarang. Jurnal Promosi Kesehatan Indonesia. Volume 10 No. 2. Agustus 2015.

Teguh Pribadi, Asro' Laelani Indrayanti,\& Elyta Vivi Yanti (2017). Peningkatan Partisipasi Masyarakat dalam Kegiatan Donor Darah di Palangka Raya. Jurnal Al-Ikhlas. Volume 3 Nomor 1, Oktober 2017. ISSN : 2461-099 